\begin{tabular}{lllllllllllllllll}
$\mathrm{S}$ & $\mathrm{T}$ & $\mathrm{U}$ & $\mathrm{D}$ & $\mathrm{I}$ & $\mathrm{A}$ & & $\mathrm{T}$ & $\mathrm{E}$ & $\mathrm{M}$ & $\mathrm{A}$ & $\mathrm{T}$ & $\mathrm{Y}$ & $\mathrm{C}$ & $\mathrm{Z}$ & $\mathrm{N}$ & $\mathrm{E}$ \\
\hline
\end{tabular}

STUDIA Z PRAWA WYZNANIOWEGO

Tom $21-2018$

DOI: https://doi.org/10.31743/spw.195

MAREK STRZAŁA*

\title{
PRAWO ODMOWY ZEZNAŃ PRZEZ DUCHOWNEGO W POLSKIEJ I NIEMIECKIEJ PROCEDURZE CYWILNEJ - ANALIZA PRAWNO-PORÓWNAWCZA
}

\section{Streszczenie}

Polski Kodeks Postępowania Cywilnego w art. $261 \S 2$ zd. 2 przewiduje możliwość odmowy zeznań przez duchownego co do faktów powierzonych mu na spowiedzi, przy czym jest to regulacja odmienna względem innych polskich procedur, które zazwyczaj zawierają w odniesieniu do takich faktów bezwzględny zakaz dowodowy. W doktrynie zgłaszane są postulaty zmiany rozwiązań zastosowanych w procedurze cywilnej, która w ocenie wielu autorów nie chroni należycie duchownych i osób powierzających im informacje. W tym stanie rzeczy punktem odniesienia są odpowiednie unormowania obce, które dostarczyć mogą gotowych rozwiązań lub wskazać właściwy kierunek zmian normatywnych, jak też zwrócić uwagę na potencjalne problemy występujące na gruncie odmiennych regulacji i ich stosowania. Celem artykułu jest przedstawienie zastosowanych w niemieckiej Zivilprozessordnung rozwiązań w zakresie prawa odmowy zeznań przez duchownego i porównanie ich z obecnymi przepisami polskiej procedury cywilnej. Analiza prawno-porównawcza obejmuje model regulacji w zakresie prawa odmowy zeznań przez duchownego, zakres podmiotowy i przedmiotowy tego prawa, kwestie dotyczące pouczenia duchownego o jego uprawnieniach, dopuszczalność składania zeznań, możliwość zwolnienia od obowiązku zachowania tajemnicy oraz zagadnienie ochrony informacji powierzonych duchownym poza sprawowaniem duszpasterstwa.

Slowa kluczowe: duchowny; świadek; zeznania; spowiedź; prawo odmowy zeznań; kodeks postępowania cywilnego; postępowanie cywilne - Polska - Niemcy;

* Dr, Zakład Prawa Kościelnego i Wyznaniowego, Wydział Prawa i Administracji, Uniwersytet Jagielloński, ul. Gołębia 9, 31-007 Kraków, e-mail: strzalamarek@gmail.com. ORCID 0000-0003-1341-3464. 
Polen - Deutschland - der Geistliche; das Zivilprozessordnung; das Zeugnisverweigerung

$* * * * *$

WPROWADZENIE

W postępowaniu cywilnym, jako opartym zasadniczo na modelu kontradyktoryjnym, ciężar gromadzenia materiału dowodowego spoczywa głównie na stronach postępowania. Istotnymi dowodami niejednokrotnie są zeznania świadków, w szczególności w sytuacji braku materiału dowodowego w postaci dokumentów. Niekiedy jednak uwzględniony przez sąd wniosek o dopuszczenie i przeprowadzenie dowodu z zeznań świadka może pozostać niezrealizowany, a to przykładowo gdy po stronie świadka brak jest woli do dobrowolnego stawienia się w toku postępowania. Strona postępowania cywilnego nie jest uprawniona do stosowania środków przymusu, a w konsekwencji nie ma możliwości zapewnienia faktycznego udziału świadka w postępowaniu. W tym stanie rzeczy, ustawodawca nałożył w Kodeksie Postępowania Cywilnego ${ }^{1}$ ustawowy obowiązek składania zeznań (art. $261 \S 1$ zd. 1 in principio k.p.c.), zaopatrzony w odpowiednie sankcje (zob. art. $274 \S 1$ k.p.c.). Realizacja uprawnień stron postępowania cywilnego do obrony ich praw, w tym w szczególności do dowodzenia istotnych dla tej obrony okoliczności faktycznych, której przejawem jest generalny obowiązek składania zeznań przez świadków, doznaje jednak niekiedy ograniczeń w przypadkach, w których zachodzi potrzeba ochrony interesów i praw osób trzecich.

Taka potrzeba zachodzi w szczególności w sytuacjach, w których świadek uzyskał wiedzę o faktach w ramach realizacji wolności religijnej, albowiem korzystanie z przysługującej każdemu wolności religijnej nie powinno łączyć się z obawą ewentualnego wykorzystania uzyskanej czy powierzonej w ramach tej realizacji wiedzy w postępowaniu sądowym, w tym przypadku - cywilnym². Dotyczy to zwłaszcza takich przypadków,

1 Ustawa z dnia 17 listopada 1964 r. Kodeks postępowania cywilnego, tekst jedn. Dz.U. z 2018 r., poz. 155 z późn. zm.

2 Por. m.in. Pieron 2012, 321; Cudak 2016, 1205, teza 20. 
w których do uzyskania lub przekazania informacji doszło w ramach wykonywania nakazów przewidzianych wyznawaną doktryną religijną albo takich, w których złożenie zeznań naruszałoby zakaz o charakterze religijnym. Tym samym wolność religijna może pozostawać w konflikcie z prawami stron postępowania cywilnego. Rolą prawodawcy jest ważyć obie wartości pozostające w konflikcie i zakreślić granice realizacji każdej z nich, co oznacza konieczność rozstrzygnięcia, w jakich przypadkach (uzasadnionych wolnością religijną) świadek będzie zwolniony od obowiązku składania zeznań. Przepisy procedury cywilnej muszą regulować ten konflikt między dążeniem do osiągnięcia i realizacji zasady prawdy materialnej, a wolnością sumienia i wyznania, tym bardziej, że na gruncie postępowania cywilnego zasada prawdy materialnej doznaje szeregu ograniczeń na rzecz zasady prawdy formalnej ${ }^{3}$. Ponieważ w praktyce uzyskiwanie informacji w związku z realizacją wolności religijnej dotyczy najczęściej osób duchownych, toteż rozstrzygając rzeczony konflikt, prawodawcy koncentrują się na ich statusie jako świadków i tak też sytuacja przedstawia się w polskiej procedurze cywilnej.

Polski Kodeks Postępowania Cywilnego ma już przeszło pół wieku, jednak jego unormowania rozstrzygające konflikt uprawnień stron postępowania cywilnego do obrony ich praw oraz wolności religijnej świadków w postaci regulacji dotyczącej możliwości odmowy składania zeznań przez duchownych (art. $261 \S 2$ zd. 2 k.p.c.) nie uległy żadnym modyfikacjom i nie zostały znowelizowane nawet po transformacjach ustrojowych. Zarazem, jak wskazuje się w doktrynie, ochrona wolności religijnej nie została uwzględniona w wystarczający sposób w przepisach kodeksowych ${ }^{4}$, z czym należy się co do zasady zgodzićs. W tym stanie rzeczy istotnych argumentów w dyskusji nad ewentualną nowelizacją Kodeksu Postępowania Cywilnego w omawianym zakresie mogą dostarczyć rozwiązania stosowane w państwach obcych. Niniejszy artykuł ma na celu przeprowadzenie analizy prawno-porównawczej obecnie obowiązujących rozwiązań

3 Por. Śladkowski 2015, 280-81.

4 Zob. m.in. Pieron 2012, 331; Rakoczy 2003, 138; Jurzyk 2004, 79; Szymański 2017,84 .

5 Poszczególne wadliwości omawianej regulacji zostały opisane niżej w ramach analizy porównawczej poszczególnych zagadnień. 
dotyczących zeznań składanych przez duchownego zastosowanych w niemieckiej procedurze cywilnej z dnia 30 stycznia 1877 r. (Zivilprozessordnung ${ }^{6}$, w skrócie: ZPO).

\section{MODEL REGULACJI W ZAKRESIE ZEZNAŃ DUCHOWNEGO}

Regulacja polska w zakresie możliwości uchylenia się przez duchownego od obowiązku złożenia zeznań ma specyficzny charakter wskutek niejednorodnej systematyki. Kodeks Postępowania Cywilnego w odniesieniu do wyjątków od zasady obowiązkowego składania zeznań w pierwszej kolejności przewiduje niezdolność zeznawania (art. 259, art. $259^{1}$ k.p.c.), ograniczoną zdolność zeznawania (art. 260 k.p.c.), ogólną zasadę obowiązku zeznawania (art. $261 \mathrm{zd}$. 1 in principio k.p.c.) oraz prawo odmowy zeznań oparte na stosunkach pokrewieństwa, powinowactwa lub przysposobienia (art. 261 $\S 1$ zd. 1 in medio i in fine oraz zd. 2 i 3 tegoż). W następnej kolejności unormowano prawo odmowy odpowiedzi na pytanie w oparciu o ewentualne negatywne konsekwencje zeznań - potencjalną odpowiedzialność karną, hańbę lub szkodę majątkową (art. $261 \S 2$ zd. 1 in principio k.p.c.), a także pogwałcenie istotnej tajemnicy zawodowej (art. $261 \S 2 \mathrm{zd}$. 1 in fine k.p.c.), by powrócić do instytucji odmowy zeznań (odróżniając ją od odmowy odpowiedzi na pytanie) przez duchownego (art. $261 \S 2$ zd. 2 in fine k.p.c.).

$\mathrm{W}$ tym stanie rzeczy utrudnione jest przeprowadzenie jednoznacznego logicznego podziału uprawnień świadków i kwalifikacja w ich kontekście statusu duchownego. Z jednej strony duchowny ma prawo odmówić zeznań, jednak dotyczącą go regulację zamieszczono poza innymi przepisami o odmowie zeznań, co mogłoby być uzasadnione ograniczeniem przedmiotowym uprawnienia duchownego (tylko odnośnie faktów powierzonych w trakcie spowiedzi), jednak przeczy temu ,przedzielenie” obu regulacji instytucją odmowy odpowiedzi na pytanie. Z drugiej strony ogólna regulacja prawa odmowy zeznań zawarta w art. $261 \S 1$ k.p.c. oparta jest na relacji świadka ze stronami postępowania, podczas gdy duchow-

${ }^{6}$ Tekst jedn. BGB1. z 2005 r. Nr 72, 3202 i n. z późn. zm. (dostępny również na stronach Federalnego Ministerstwa Sprawiedliwości i Ochrony Konsumentów: https://www. gesetze-im-internet.de/zpo/BJNR005330950.html [dostęp: 17.03.2018]). 
ny może odmówić zeznań nie tylko w sytuacji, gdy fakty powierzyła mu w trakcie spowiedzi strona postępowania.

Podobne trudności pojawiają się z ustaleniem relacji pomiędzy uprawnieniami duchownego do odmowy zeznań a innymi przypadkami możliwości odmowy realizowania obowiązku składania zeznań, o których mowa w art. $261 \S 2$ k.p.c. Rzeczone przypadki dotyczą prawa odmowy odpowiedzi na pytanie z powodu potencjalnych negatywnych konsekwencji dla świadka lub osób pozostających z nim w określonych relacjach (w odróżnieniu od ogólnego prawa odmowy zeznań w całości w przypadku pozostawania w takich relacjach). W tym zakresie można upatrywać podobieństwa w przypadku osób duchownych i tajemnicy spowiedzi, a to wobec łączących się z zeznaniami negatywnych konsekwencji dla duchownego (wynikających np. z prawa wewnętrznego wspólnoty religijnej). Przeciwko jednak traktowaniu zeznań duchownego w tym kontekście przemawia przyznanie duchownemu innego uprawnienia, a to prawa odmowy zeznań w miejsce prawa odmowy odpowiedzi na pytanie, jak też zamieszczenie dotyczących go regulacji oddzielnie - po tajemnicy zawodowej, stanowiącej oddzielny powód prawa odmowy zeznań względem negatywnych konsekwencji opisanych w pierwszej części art. $261 \S 2$ zd. 1 k.p.c. ${ }^{7}$ Tym samym wątpliwe jest kwalifikowanie prawa odmowy zeznań duchownego odnośnie faktów powierzonych w kategoriach tajemnicy zawodowej ${ }^{8}$.

7 Oddzielne unormowanie prawa odmowy zeznań przez duchownego w art. $261 \S 2$ zd. 2 k.p.c. ma także tę logiczną konsekwencję, że ustawodawca wydaje się nie traktować naruszenia tajemnicy spowiedzi w kategoriach czynu, który mógłby narazić duchownegoświadka na negatywne konsekwencje (np. hańbę czy odpowiedzialność karną za popełnienie przestępstwa z art. $266 \S 1$ ustawy z dnia 6 czerwca 1997 r. Kodeks karny, tekst jedn. Dz.U. z 2017 r., poz. 2204 z późn. zm.). W tej interpretacji duchowny nie mógłby powoływać się w zakresie informacji powierzonych mu w trakcie spowiedzi na uprawnienie do odmowy odpowiedzi na pytanie w oparciu o powołany przepis procedury cywilnej, skoro jego uprawnienia zostały ukształtowane odrębnie. Nie przesądzając w tym miejscu o słuszności przedstawionej wyżej wykładni, ma ona tę zaletę, że otwiera możliwość duchownemu powoływania się w sytuacjach nie objętych zakresem zastosowania art. 261 § 2 zd. 2 k.p.c. na prawo odmowy odpowiedzi na pytanie ze względu na potencjalne negatywne konsekwencje, o których mowa w art. $261 \S 2$ zd. 1 k.p.c. Przykładowo dotyczyć to może duchownych wspólnot religijnych działających tylko faktycznie (,nieuznanych”) czy duchownych wyznań „uznanych” w zakresie informacji uzyskanych poza spowiedzią.

8 Por. odmiennie: Stanisz 2011, 294; Skąpski 1981, 68. 
W rezultacie uprawnienie duchownego do odmowy zeznań co do faktów powierzonych mu na spowiedzi w ramach Kodeksu Postępowania Cywilnego jawi się jako uprawnienie sui generis. W istocie trudno wskazać, jakie względy przemawiały za zamieszczeniem regulacji dotyczącej uprawnień duchownego w tym a nie innym miejscu przepisów Kodeksu Postępowania Cywilnego dotyczących uprawnień świadków. Rodzi to trudność w ustaleniu aksjologii wprowadzonego prawa odmowy zeznań przez duchownego, a w konsekwencji i w dokonaniu wykładni teleologicznej. W szczególności przedstawiona wyżej redakcja Kodeksu utrudnia jednoznaczne określenie, czy art. $261 \S 2$ zd. 2 k.p.c. ma na celu w pierwszej kolejności ochronę duchownego ${ }^{9}$ czy penitenta, co mogłoby pomóc w rozstrzygnięciu pojawiających się trudności, w szczególności w razie konfliktu między interesami duchownego oraz penitenta.

Opisane trudności z systematyką i kwalifikacją uprawnień duchownych w zakresie publiczno-prawnego obowiązku (przymusu) składania zeznań (die Zeugnispflicht, der Zeugniszwang) zasadniczo nie występują na gruncie procedury niemieckiej. Uprawnienia duchownego w tym zakresie zostały unormowane $\mathrm{w}$ ramach przepisu regulującego prawo do odmowy zeznań z powodów podmiotowych (das Zeugnisverweigerung aus persönlichen Gründen), które wyraźnie odróżnia się od prawa odmowy odpowiedzi na pytanie, które jest oparte na przewidzianych w $\S 384$ ZPO przesłankach przedmiotowych (das Zeugnisverweigerung aus sachlichen Gründen $)^{10}$. Zastosowane kryterium w procedurze niemieckiej jest jednoznaczne w tym sensie, że dzieli uprawnienia świadków na te, które są oparte na cechach osoby świadka (np. relacjach ze stroną, wykonywanym zawodem lub pełnieniem funkcji związanej z obowiązkiem zachowania tajemnicy) oraz na te, których przesłanki dotyczyć mogą świadka niezależnie od jego cech indywidualnych ${ }^{11}$.

W efekcie zastosowanej systematyki procedura niemiecka wydaje się traktować prawo odmowy zeznań przez duchownego nie jako regulację sui generis, ale jako przykład uprawnienia przysługującego ze względu na szczególny status świadka, a nie na potencjalne negatywne dla niego

9 Tak np. Jurzyk 2004, 80.

10 Zob. Huber 2009, 1254, nb. 1.

11 Por. nieco odmiennie: Berger 1999, 279, nb. 13 i 280, nb. 16. 
konsekwencje. Przemawia to za przyjęciem, że u podstaw omawianego wyjątku od obowiązku składania zeznań, leży nie ochrona samego świadka (będącego zarazem) duchownym przed niekorzystnymi konsekwencjami składania zeznań (jak to ma miejsce w przypadku odmowy z powodów obiektywnych, o których mowa w $§ 384$ ZPO), lecz poszanowanie roli, jaką pełnią duchowni, a tym samym interesów i praw osób korzystających z ich pomocy. Innymi słowy, prawo odmowy zeznań przez duchownego należy interpretować nie w kontekście ochrony osoby duchownego, lecz przez pryzmat jego funkcji jako duchownego, a więc osoby powołanej do posługi duszpasterskiej (zob. niżej), z którą (co do zasady) wiąże się poufność ${ }^{12}$. W konsekwencji w razie konfliktu między interesami duchownego a osoby korzystającej z jego pomocy omawiane unormowanie zdaje się przyznawać pierwszeństwo interesom tej ostatniej ${ }^{13}$.

\section{ZAKRES PODMIOTOWY}

Kodeks Postępowania Cywilnego prawo do odmowy składania zeznań przyznaje w art. $261 \S 2$ zd. 2 wyłącznie „duchownym”"14. Zgodnie z $§ 383$ ust. 1 pkt 4 ZPO do uchylenia się od obowiązku składania zeznań uprawnieni są duchowni (Geistliche) ${ }^{15}$, przy czym pojęcie to nie zostało bliżej dookreślone. Zatem w omawianym zakresie redakcja przepisu jest

12 Por. Greger 2016, 1235, nb. 1a; Eichele 2007, 901, nb. 7. Zob. też nieco odmiennie, upatrując założeń omawianej regulacji w woli zaoszczędzenia świadkowi konfliktu obowiązków oraz potencjalnie obniżonej wskutek takiego konfliktu wartości zeznań - Berger 1999, 277, nb. 1. Podobnie: Trautwein 2010, 1055, nb. 1 i 1056, nb. 15. Zob. też: Baumbach, Lauterbach, Albers i Hartmann 1999, 1483, nb. 2. Niekiedy uprawnień duchownego do odmowy złożenia zeznań upatruje się bezpośrednio w wolności religijnej-zob. Robbers 2010, 252.

13 Analizując cel omawianego uprawnienia do odmowy zeznań w literaturze wskazuje się również na to, że jego wprowadzenie ułatwia wykonywanie zawodu przez osoby uprawnione. Zob. Huber 2009, 1254, nb. 1.

14 Por. m.in. Cudak 2016, 1205, teza 20.

15 „Zur Verweigerung des Zeugnisses sind berechtigt: (...) 4. Geistliche in Ansehung desjenigen, was ihnen bei der Ausübung der Seelsorge anvertraut ist; (...)“. Tłum.: „Mają prawo odmówić zeznania: (...) 4. duchowni co do tego, co im powierzono przy sprawowaniu duszpasterstwa; (...)". Tłum. za: Ustawa o postępowaniu cywilnem obowiązująca na 
zupełnie analogiczna do polskiej. W konsekwencji zarówno w Polsce, jak i w Niemczech, pojawia się zagadnienie wykładni tego pojęcia.

Zasadniczo możliwe są dwie koncepcje w zakresie wykładni terminu „duchowny”. Pierwsza, w świetle której pojęcie duchownego należy interpretować przez pryzmat prawa własnego wspólnot religijnych, oraz druga, opierająca się na autorytatywnym nadaniu zakresu semantycznego przez prawodawcę państwowego. Wyróżniane są one odpowiednio w literaturze jako oparte o zastosowanie kryterium „wewnętrznego” lub „zewnętrznego"16. Można je również określić odpowiednio jako koncepcje wykładni odsyłającej (przejmującej na zasadzie recepcji do państwowego porządku prawnego, w tym przypadku procedury cywilnej, normy prawa wewnętrznego wspólnot religijnych) oraz wykładni autonomicznej (abstrahującej od regulacji prawa własnego wspólnot religijnych, wprowadzającej własne pojęcie duchownego na potrzeby prawa państwowego).

Orzecznictwo sądowe w Polsce wydaje się łączyć poniekąd obie z prezentowanych koncepcji interpretacyjnych, wskazując, że duchowny to osoba, która jest powołana do stałego organizowania i pełnienia kultu, przy czym fakt tego powołania ma być ustalany na podstawie prawa własnego wspólnoty religijnej ${ }^{17}$ (nie można jednak pominąć, że orzeczenia te zapadały na gruncie innych stanów faktycznych niż składanie zeznań, a to uprawnienia duchownych do odmowy odbycia zasadniczej służby wojskowej). Wydaje się zbliżony pogląd prezentuje orzecznictwo niemieckie, które stara się interpretować pojęcie duchownego w sposób autonomiczny, a to przez pryzmat realizowanych przez daną osobę zadań, niezależnie od rozumienia samego terminu ,duchowny” w prawie wewnętrznym, zarazem jednak analizując w kontekście prawa własnego wspólnoty religijnej samą kwestię wypełniania tych obowiązków. Mianowicie, uznaje się za duchownego w rozumieniu $§ 383$ ust. 1 pkt 4 ZPO także osoby bez święceń kapłańskich w rozumieniu prawa wewnętrznego wspólnoty religijnej, o ile realizują one samodzielnie w imieniu Kościoła zadania

Ziemiach Zachodnich Rzeczypospolitej Polskiej (Warszawa: Ministerstwo Sprawiedliwości; Poznań: Skład Główny Księgarnia Św. Wojciecha, 1923), 77.

16 Zob. Jurzyk 2004, 72. Tak również: Pieron 2012, 331.

17 Zob. Strzała 2017, 112, przyp. 22. Zob. też: (w tym również odnośnie rozumienia duchownego przez judykaturę amerykańską) Jurzyk 2004, 72-73. Por. Knoppek 2013, 919, teza 16; Pieron 2017, 156-58. 
o charakterze duszpasterskim ${ }^{18}$. Tym samym w Republice Federalnej Niemiec zasadniczo nie powstaje występujący w Polsce problem kwalifikacji zakonników jako duchownych ${ }^{19}$.

Osobnym zagadnieniem względem samego pojmowania duchownego jest kwestia ewentualnego ograniczenia uprawnień w zakresie zeznawania do duchownych ściśle określonych wyznań. Polska doktryna postępowania cywilnego uznaje, że przez duchownego w rozumieniu art. $261 \S 2 \mathrm{zd}$. 2 k.p.c. należy rozumieć wyłącznie duchownego tzw. prawnie uznanych wyznań $^{20}$. Choć obecnie prawodawca wydaje się raczej rezygnować z używania pojęcia prawnie uznanych wyznań, można przyjąć, że zaliczają się do nich kościoły lub inne związki wyznaniowe, których status reguluje indywidualny akt prawa powszechnie obowiązującego (ustawa lub umowa międzynarodowa), bądź które zostały zarejestrowane na podstawie ustawy o gwarancjach wolności sumienia i wyznania ${ }^{21}$. Bez dokonywania w tym miejscu szczegółowej analizy zagadnienia należy w tym miejscu jedynie wskazać, że takiemu ograniczeniu tajemnicy spowiedzi do wspólnot religijnych „uznanych” można przeciwstawić poważne kontrargumenty ${ }^{22}$.

18 Zob. Trautwein 2010, 1057, nb. 17; Greger 2016, 1236-37, nb. 11; Damrau 2008, 2306, nb. 22; Huber 2009, 1256, nb. 5 oraz powoływane tam orzeczenie Federalnego Trybunału Sprawiedliwości z dnia 15 listopada 2006 r., StB 15/06, w którym (na gruncie analogicznego przepisu procedury karnej) uznano za duchownego osobę świecką pełniącą funkcję etatowego, samodzielnego duszpasterza zakładu karnego. Orzeczenie dostępne jest online na stronie: http://juris.bundesgerichtshof.de/cgi-bin/rechtsprechung/document.py?Gericht= bgh\&Art $=$ en $\& n r=38215 \&$ pos $=0 \& a n z=1$ [dostęp: 05.04 .2018$]$.

19 Zob. Jurzyk 2004, 73.

20 Zob. m.in. Demendecki 2017, 471; Flaga-Gieruszyńska 2017, 521, teza 6 z powołaniem na orzecznictwo międzywojenne; Ereciński 2016, 386, teza 14; Knoppek 2013, 919 , teza 16 również z powołaniem na orzecznictwo międzywojenne. Zob. też: Pieron 2012, 332.

21 Ustawa z dnia 17 maja 1989 r. o gwarancjach wolności sumienia i wyznania, tekst jedn. Dz.U. z 2017 r., poz. 1153.

22 Podstawowy zarzut dotyczy wprost treści art. $261 \S 2$ zd. 2 k.p.c., który nie zawiera żadnych ograniczeń w zakresie korzystania z prawa odmowy składania zeznań do duchownych wyznań prawnie uznanych. Zatem lege non distinguente należy przyjąć, że komentowany przepis dotyczy wszystkich wyznań. Interpretację tę wzmacnia również konstytucyjna zasada równouprawnienia wyznań. Ponadto odwoływanie się do orzecznictwa międzywojennego uzasadniającego uznawanie za duchownych w rozumieniu powołanego przepisu wyłącznie duchownych prawnie uznanych wyznań jest dyskusyjne, gdyż obecnie obowiązujące rozwiązania konstytucyjne w zakresie ustroju wyznaniowego państwa róż- 
Okazuje się, że podobną, zawężającą interpretację terminu „duchowny" prezentuje doktryna niemiecka na gruncie ZPO. Wskazuje $\operatorname{się}^{23}$, iż $\S 383$ ust. 1 pkt 4 ZPO dotyczy wyłącznie duchownych prawnie uznanych wyznań w rozumieniu utrzymanego w mocy przez art. 140 Konstytucji Republiki Federalnej Niemiec ${ }^{24}$ (Grundgesetz für die Bundesrepublik Deutschland) przepisu art. 137 ust. 5 Konstytucji Republiki Weimarskiej ${ }^{25}$ (Weimarer Rechtsverfassung), a więc wyłącznie wspólnot religijnych o statusie podmiotów prawa publicznego. W konsekwencji wyłączenie od obowiązku składania zeznań na mocy omawianego przepisu niemieckiej procedury cywilnej obejmować będzie tylko duchownych wspólnot religijnych uznanych, a więc tych uznanych bezpośrednio z mocy niemieckich przepisów konstytucyjnych bądź uznanych na mocy przepisów poszczególnych niemieckich krajów związkowych ${ }^{26}$. Do pierwszej grupy należy zaliczyć Kościół Rzymskokatolicki, Kościół Ewangelicko-Augsburski, poszczególne gminy żydowskie, Kościół Starokatolicki, Kościół Staroluterski, Kościół Baptystów oraz Kościół Menonicki²7.

Trzeba jednak wskazać, że w przypadku Republiki Federalnej Niemiec stanowisko powyższe ma podstawy w unormowaniach konstytucyjnych,

nią się znacznie od międzywojennych unormowań. Wydaje się, że liczebność wspólnoty religijnej, która jest de facto warunkiem jej rejestracji jest nieproporcjonalnym kryterium ograniczania wolności religijnej w zakresie możliwości odmowy złożenia zeznań przez duchownego. Jest tak tym bardziej, jeśli przyjąć, że celem omawianej regulacji nie jest ochrona duchownego, lecz osoby, która powierzyła informacje w trakcie spowiedzi.

23 Zob. Damrau 2008, 2306, nb. 22; Greger 2016, 1236, nb. 11; Huber 2009, 1256, nb. 5; Eichele 2007, 902, nb. 8; Trautwein 2010, 1057, nb. 17. Wydaje się odmiennie: Baumbach, Lauterbach, Albers i Hartmann 1999, 1483, nb. 5. Zob. też: Berger 1999, 284, nb. 36 i $290-1$, nb. 89.

${ }^{24}$ Konstytucja Republiki Federalnej Niemiec z dnia 23 maja 1949 r., BGBl. z 1949 r. Nr 1, s. 1 i n. z późn. zm. Tekst polski: Janicki 2007, 65-331; Banaszak i Malicka 2008, 37-114.

25 Konstytucja Rzeszy Niemieckiej z dnia 11 sierpnia 1919 r., DRGB1. z 1919 r. Nr 152, s. 1383-1418. Tekst polski: Janicki 2007, 317-20; Banaszak i Malicka 2008, 115-16.

26 Zob. Classen 2006, 126-30; Fundowicz 1999, 57-58; Friedner 2007, 112; Robbers 2010, 148-50.

27 Listę pozostałych wspólnot religijnych o statusie korporacji prawa publicznego można odnaleźć na oficjalnych stronach Federalnego Ministerstwa Spraw Wewnętrznych: https://www.personenstandsrecht.de/PERS/DE/Themen/Informationen/Religionsgemeinschaften/kirche_berlin.html;jsessionid=475041D450A18A76D19B5D898D8E8AAC.1_ cid364?nn=4057350 [dostęp: 05.04.2018]. 
rozróżniających wspólnoty religijne o statusie prawa publicznego i prawa prywatnego, a które to rozróżnienie nie występuje w polskim porządku prawnym. Ponadto omawiane ograniczenie prawa odmowy zeznań do duchownych uznanych wspólnot religijnych może być również uzasadniane tym, iż duchowni pozostałych wyznań mogą odmówić zeznań na podstawie $\S 383$ ust. 1 pkt $6 \mathrm{ZPO}^{28}$, co w rezultacie nie prowadzi do dyskryminacji żadnej wspólnoty religijnej i powoduje, że zagadnienie to staje się czysto teoretyczne. Zatem regulacja niemiecka nie stanowi uzasadnienia do odmówienia duchownym ,nieuznanych” wspólnot religijnych skorzystania z uprawnienia, o jakim mowa w art. $261 \S 2$ zd. 2 k.p.c.

Podsumowując zakres podmiotowy porównywanych unormowań, trzeba wskazać, że na gruncie obu regulacji szereg kwestii pozostało nierozwiązanych. W szczególności w przypadku podsłuchiwania spowiedzi przez osoby trzecie, ale także sytuacji pozostawania w błędzie przez penitenta co do tego, że przekazuje informacje osobie, która nie jest duchownym (np. gdy rzekomy spowiednik udaje duchownego), treść przepisów nie upoważnia do odmowy zeznań ${ }^{29}$. Doktryna polska upatruje tutaj szansy w wykładni per analogiam ${ }^{30}$, podnosząc, że tajemnica spowiedzi chroni głównie penitenta ${ }^{31}$. Nie zajmując stanowiska w tej kwestii w tym miejscu, można jednak wskazać, że wykładnia taka (w swej istocie teleologiczna) jest nieco bardziej uprawniona na gruncie przepisów niemieckich, a to wobec większej przejrzystości ich aksjologii ${ }^{32}$.

\section{ZAKRES PRZEDMIOTOWY}

W świetle treści art. $261 \S 2$ zd. 2 k.p.c. polskie unormowania chronią wyłącznie informacje powierzone duchownemu na spowiedzi. Dokonując analizy logicznej przedmiotowego przepisu, przesłankami uprawnienia do odmowy zeznań są: powierzenie, spowiedź oraz duchowny jako adresat in-

28 Damrau 2008, 2306, nb. 22; Greger 2016, 1236, nb. 11; Eichele 2007, 902, nb. 8; Trautwein 2010, 1057, nb. 17.

29 Zob. odnośnie regulacji polskiej: Cudak 2016, 1206, teza 20.

30 Rakoczy 2003, 133. Odmiennie: Cudak 2016, 1205-06, teza 20.

31 Rakoczy 2003, 133.

32 Zob. wyżej. 
formacji ,powierzonej"33. Samym powierzeniem i jego adresatem w kontekście przesłanek prawa odmowy zeznań doktryna polska wydaje się zajmować w stosunkowo niewielkim zakresie, koncentrując się głównie na pojęciu spowiedzi ${ }^{34}$. Tymczasem można sobie wyobrazić przykładowo sytuację, w której penitent przekazuje w trakcie spowiedzi także takie informacje, co do których nie oczekuje ich zachowania w poufności, a nawet może prosić duchownego o ich dalsze przekazanie lub nawet upublicznienie. Teoretycznie możliwe jest również, że w trakcie spowiedzi penitent będzie wypowiadał słowa, których adresatem niekoniecznie musi być duchowny (sytuacja taka może mieć miejsce zwłaszcza w przypadku niektórych chorób psychicznych).

Słowo ,powierzyć” nie oznacza prostego przekazania informacji, lecz „ujawnić coś poufnie" 35 (tym samym np. spowiedź powszechna, stanowiąca upublicznienie informacji, nie jest objęta ochroną) ${ }^{36}$. Wyraźny jest etymologiczny związek pojęcia ,powierzenia” z wiarą w osobę, której informacja jest przekazywana, a tym samym wzmacnia on argumentację, że celem komentowanych przepisów jest w pierwszej kolejności ochrona osoby przekazującej informacje, a nie duchownego. Warto odnotować w tym miejscu użycie w kodeksie niemieckim czasownika rozdzielnie złożonego anvertrauen. Wydaje się on nadal zachowywać konotacje językowe do-

33 Nieco bardziej dyskusyjne jest, czy użycie terminu ,fakt” w treści art. $261 \S 2 \mathrm{zd}$. 2 ma jakieś poważniejsze znaczenie normatywne. Przy rygorystycznej wykładni, przeprowadzając znane polskiemu prawu cywilnemu rozróżnienie oświadczeń wiedzy, woli i emocji, można by uznać, że prawo odmowy zeznań obejmuje wyłącznie treść tych pierwszych (w tej interpretacji ochronie nie podlegałyby np. oceny formułowane przez penitenta, a które mogłyby mieć znaczenie chociażby z punktu widzenia dowodzenia jego złej wiary). Zarazem wola wywołania określonych skutków czy stan emocjonalny mieszczą się w zwykłym znaczeniu słowa „fakt”. Wobec braku definicji legalnej, gwarancyjnego charakteru powołanego przepisu, trudności praktycznych ze stosowaniem ograniczenia przedmiotowego do oświadczeń wiedzy oraz uwzględniając kontekst teleologiczny, należy przyjąć, że przez fakt należy rozumieć nie tyle okoliczność faktyczną, ile informację. W tym więc również należy upatrywać przewagi regulacji niemieckiej, która nie stanowi o „faktach” powierzonych, ale używa zaimka bez własnej treści semantycznej, stanowiąc, że duchowny może odmówić zeznań „,co do tego”, co zostało powierzone.

34 Zob. niżej.

35 Dubisz 2003, 463, v. powierzyć-powierzać.

36 Tak m.in.: Pieróg 2015, 176. 
tyczące zaufania do adresata wiadomości i woli zachowania informacji w poufności, niż polski termin „,powierzenie”, który wydaje się konotacje te powoli tracić.

W doktrynie niemieckiej podkreśla się, iż w przeciwieństwie do niemieckiej procedury karnej, przepisy Zivillprozessordnung ograniczają zwolnienie dotyczące zeznań duchownych wyłącznie do informacji ,powierzonych" w związku z czynnościami duszpasterskimi, a nie „uzyskanych" w ich ramach, a zatem prawo odmowy zeznań uzależnione jest od woli zachowania informacji w poufności ${ }^{37}$. Podnosi się również, że kluczowe jest, by na mocy prawa publicznego lub prywatnego świadek był zobowiązany do zachowania informacji w poufności ${ }^{38}$, choć zdarzają się głosy, iż samo istnienie zobowiązania materialnoprawnego jest irrelewantne dla omawianego uprawnienia procesowego ${ }^{39}$. Akceptując powyższe, niemiecka judykatura prezentuje pogląd, że powierzenie jest warunkiem zastosowania $\S 383$ ust. 1 pkt 4 ZPO, jednak samo powierzenie nie wymaga wyraźnego zastrzeżenia poufności, o ile tylko osoba powierzająca informacje miała prawo oczekiwać zachowania przekazywanych informacji w tajemnicy ${ }^{40}$. Innymi słowy, zastrzeżenie poufności jest warunkiem skorzystania z prawa odmowy zeznań, ale może być konkludentne ${ }^{41}$. Nie można też pominąć, że warunkiem powierzenia nie jest to, aby fakty powierzane nie były znane osobom trzecim ${ }^{42}$.

Odnośnie przesłanki przekazywania informacji duchownemu jako jej adresatowi trzeba wskazać, że z uwagi na jej głównie teoretyczny charakter kwestia ta podobnie jak w Polsce nie jest przedmiotem szczegółowych rozważań komentatorów Zivillprozessordnung. Wskazuje się jedynie na to, że $\S 383$ ust. 1 pkt 4 ZPO obejmuje tylko informacje przekazane, a więc uzyskane przez duchownego na skutek działań osoby przekazującej informacje,

37 Damrau 2008, 2306, nb. 23.

38 Greger 2016, 1237, nb. 16.

39 Zob. Berger 1999, 281, nb. 21.

40 Reichold 2012, 651, nb. 4. Por. Berger 1999, 285, nb. 37; Huber 2009, 1256, nb. 4; Trautwein 2010, 1056, nb. 15; Baumbach, Lauterbach, Albers i Hartmann 1999, 1483, nb. 5.

41 Warto odnotować też pogląd, że tajemnica rozciągać się może także na sam fakt powierzenia (np. obejmować może to, czy w ogóle miała miejsce spowiedź). Zob. Damrau 2008, 2306, nb. 23.

42 Berger 1999, 285, nb. 37; Damrau 2008, 2306, nb. 23. 
przeciwstawiając je w tym zakresie regulacji $§ 383$ ust. 1 pkt 6 ZPO, która uprawnia do odmowy zeznań także w zakresie informacji uzyskanych na skutek własnych działań świadka ${ }^{43}$. Rozpatrując kwestię stron czynności powierzenia informacji, trzeba też odnotować, że uprawnienie duchownego do odmowy zeznań obejmuje zarówno informacje przekazane przez stronę postępowania cywilnego, ale też przez osoby trzecie (np. innych świadków) ${ }^{44}$, co jest rozwiązaniem obecnym również na gruncie polskiej procedury.

Podstawowej różnicy pomiędzy regulacjami polskimi i niemieckimi należy upatrywać w zakresie czynności, w ramach których dochodzi do przekazania informacji, a uprawniających do odmowy zeznań. O ile polski prawodawca przewidział możliwość uchylenia się przez duchownego od obowiązku zeznań wyłącznie co do informacji powierzonych w ramach spowiedzi, o tyle takiego ograniczenia nie zawiera niemiecka procedura cywilna ${ }^{45}$. Przewiduje ona mianowicie, że duchowny może odmówić zeznań odnośnie tego, co zostało mu powierzone przy sprawowaniu duszpasterstwa (in Ansehung desjenigen, was ihnen bei der Ausübung der Seelsorge anvertraut ist). Tym samym znacznie szerszy jest zakres dopuszczalnej odmowy zeznań przez duchownych prawnie uznanych wyznań, gdyż oprócz spowiedzi obejmować on będzie również np. rozmowy o charakterze duszpasterskim czy tzw. ogólne kierownictwo duchowe, a więc te formy aktywności duszpasterskiej duchownych, które w Polsce nie są chronione literalnym brzmieniem art. $262 \S 2$ zd. 2 k.p.c. ${ }^{46}$ Bynajmniej jednak rzeczone uprawnienie duchownego nie obejmuje całokształtu jego aktywności. Jednoznacznie uznaje się, że nie są objęte prawem odmowy zeznań informacje pozyskane przez duchownego w ramach prowadzenia spraw związanych z organizacją i zarządem kościoła, charytatywnością czy edukacją ${ }^{47}$.

43 Tamże, 2308, nb. 32.

44 Zob. m.in. Eichele 2007, 901, nb. 7; Berger 1999, 284, nb. 35.

45 Godzi się w tym miejscu odnotować, że literalnie Kodeks Postępowania Cywilnego nie dotyczy faktów powierzonych „w trakcie” spowiedzi, ale faktów powierzonych „na” spowiedzi, co stanowić może przyczynek dla interpretacji, że przedmiotem ochrony są wyłącznie fakty stanowiące bezpośrednio wyznawane winy, a nie fakty podawane w trakcie spowiedzi niejako ,przy okazji”.

46 Majer 2002, 113-14. Zob. też: Domaszk 2016, 35; Pieron 2016, 132; Pieron 2017, 168.

47 Zob. Huber 2009, 1256, nb. 5; Damrau 2008, 2306, nb. 24; Greger 2016, 1237 , nb. 11; Eichele 2007, 902, nb. 8; Baumbach, Lauterbach, Albers i Hartmann 1999, 1483, nb. 5. 
Rozpatrując formę powierzenia informacji, przyjmuje się na gruncie polskiej regulacji ograniczającej się do spowiedzi, że przekazanie informacji dotyczy tylko tzw. spowiedzi usznej i co więcej mającej charakter sakramentalny ${ }^{48}$. Tymczasem na gruncie nie znającej takiego ograniczenia niemieckiej procedury cywilnej, przyjmuje się że sposób przekazania informacji jest całkowicie bez znaczenia dla skorzystania z uprawnienia duchownego do odmowy złożenia zeznań. Ochronie podlega zarówno informacja przekazana ustnie, w rozmowie telefonicznej, a nawet w liście ${ }^{49}$.

\section{OBOWIĄZEK POUCZENIA DUCHOWNEGO O UPRAWNIENIACH}

Dokonując analizy porównawczej prawa odmowy złożenia zeznań w niemieckim i polskim kodeksie, warto przedstawić również proceduralne aspekty realizacji tego uprawnienia, w szczególności obowiązki sądu w zakresie poinformowania duchownego o jego uprawnieniach. Polski Kodeks Postępowania Cywilnego przewiduje w art. $266 \S 1$ in principio obowiązek pouczenia świadka przed przystąpieniem do jego przesłuchania o prawie odmowy zeznań. Ponieważ duchowny na gruncie polskiej procedury jest uprawniony do odmowy zeznań, również jego obejmuje obowiązek pouczenia przez sąd.

Odmiennie przedstawia się sytuacja w Republice Federalnej Niemiec. Obowiązujące przepisy różnicują w przedmiotowym zakresie status podmiotów uprawnionych na podstawie $\S 383$ ust. 1 do odmowy zeznań. Obowiązek pouczenia został ograniczony wyłącznie do osób wymienionych w powołanym przepisie w pkt 1-3, a zatem nie obejmuje on duchownych i w konsekwencji sąd nie jest zobowiązany do poinformowania duchownego o jego uprawnieniu do odmowy zeznań (arg. a contrario $§ 383$ ust. 2 ZPO). Jest to jedna $\mathrm{z}$ niewielu sytuacji, w której przepisy polskiego postępowania cywilnego przewidują większy stopień ochrony duchownego i osób powierzających im informacje niż analogiczna regulacja niemiecka ${ }^{50}$.

48 Zob. Knoppek 2013, 919, teza 16.

49 Zob. Damrau 2008, 2306, nb. 23. Por. Baumbach, Lauterbach, Albers i Hartmann 1999, 1483, nb. 5.

50 Uzupełniając uwagi dotyczące procesowych aspektów realizacji prawa do odmowy zeznań, warto dodać także, że zgodnie z $\$ 386$ ust. 2 ZPO świadek jest zobowiązany uprawdopodobnić istnienie obowiązku zachowania tajemnicy, przy czym w przypadku m.in. du- 
DOPUSZCZALNOŚĆ SKŁADANIA ZEZNAŃ PRZEZ DUCHOWNEGO

Poważnym zagadnieniem jest kwestia względnego charakteru zakazu dowodowego dotyczącego faktów powierzonych duchownemu, o ile właściwszym określeniem tego problemu nie jest możliwość nie korzystania przez niego z uprawnienia do odmowy zeznań. Przepis art. $261 \S 2$ zd. 2 k.p.c. przewiduje ,prawo” odmowy zeznań przez duchownego, co oznacza, iż może on z tego prawa nie korzystać, składając zeznania odnośnie faktów powierzonych mu na spowiedzi.

Nie inaczej jest na gruncie niemieckiej procedury cywilnej ${ }^{51}$, która jednak nawet w sytuacji braku skorzystania przez duchownego z prawa odmowy składania zeznań próbuje chronić osobę, która powierzyła mu informacje oraz łączący je stosunek zaufania. Zgodnie bowiem z $§ 383$ ust. 3 ZPO przesłuchanie duchownego, nawet gdy nie skorzystał on ze swojego uprawnienia do odmowy składania zeznań, nie powinno zmierzać do ustalania takich faktów, co do których jest oczywiste, że nie jest możliwe ich złożenie bez naruszenia zobowiązania do zachowania tajemnicy. W efekcie sąd powinien z urzędu zadawać odpowiednie pytania, aby uniknąć naruszenia zobowiązania do zachowania informacji w poufności ${ }^{52}$. Niektórzy autorzy podnoszą, że regulacja ta ma na celu ochronę świadka przed naruszeniem jego zobowiązań ${ }^{53}$ oraz wskazują, że w niektórych przypadkach także ogół może być zainteresowany zachowaniem tajemnicy ${ }^{54}$. Przepis ten ma jednak charakter lex imperfecta, gdyż naruszenie opisanego obowiązku przez sąd nie powoduje niemożności wykorzystania zeznañ ${ }^{55}$ (tak samo będzie również w sytuacji, gdy świadek ujawni coś z naruszeniem tajemnicy nawet bez pytania ${ }^{56}$ ). Podobnie, nawet jeśli duchowny skorzy-

chownych wystarczające jest odpowiednie zapewnienie. Zob. szerzej: Damrau 2008, 2321, nb. 6; Reichold 2012, 655, nb. 1; Huber 2009, 1261, nb. 1-2.

51 Zob. m.in. Eichele 2007, 902, nb. 7.

52 Damrau 2008, 2311-12, nb. 42. Por. Huber 2009, 1254, nb. 1 i 1257, nb. 7; Eichele 2007, 903, nb. 18; Berger 1999, 294, nb. 106-8; Trautwein 2010, 1057, nb. 16.

53 Zob. Damrau 2008, 2311, nb. 42.

54 Zob. Reichold 2012, 652, nb. 11.

55 Damrau 2008, 2311, nb. 42. Por. Reichold 2012, 652, nb. 11; Huber 2009, 1257 , nb. 9; Eichele 2007, 901-3, nb. 2, 12 i 18; Trautwein 2010, 1057, nb. 16.

56 Damrau 2008, 2311, nb. 42. 
stał z prawa odmowy zeznań, to można wykorzystać jego zeznania złożone $\mathrm{w}$ innym postępowaniu, gdyż nie są już objęte tajemnicą ${ }^{57}$.

\section{ZWOLNIENIE OD OBOWIĄZKU ZACHOWANIA TAJEMNICY}

Nie ma wątpliwości, iż na gruncie polskiego postępowania cywilnego dysponentem uprawnienia, o którym mowa w art. $261 \S 2$ zd. 2 k.p.c. jest duchowny. Penitent, nawet gdy jest zainteresowany zeznaniami duchownego, nie może skutecznie doprowadzić do złożenia przez tego ostatniego zeznań, jeśli skorzysta on z prawa odmowy zeznań ${ }^{58}$.

Przewidując potencjalny konflikt pomiędzy prawami świadka a interesem osoby, która powierzyła mu w zaufaniu informację, § 385 ust. 2 ZPO przewiduje, iż świadek nie może odmówić składania zeznań, jeśli został zwolniony z obowiązku zachowania tajemnicy ${ }^{59}$. Założeniem tej regulacji jest to, że jeśli prawo odmowy zeznań w założeniu ma służyć ochronie interesów osoby przekazującej duchownemu informacje, to w przypad$\mathrm{ku}$ zwolnienia przez nią duchownego z obowiązku zachowania tajemnicy zrzeka się tym samym ochrony, a cel ustanowionego prawa odmowy zeznań dezaktualizuje się ${ }^{60}$. Wskazuje się również na to, że możliwość taka nie zachodzi w przypadku upublicznienia informacji lub gdy świadek został upoważniony do przekazania informacji osobom trzecim ${ }^{61}$.

Nawet jednak gdy świadek zostanie zwolniony z obowiązku tajemnicy, nadal może odmówić zeznań, jeśli normy prawa państwowego w dalszym ciągu nakładają na niego obowiązek poufności ${ }^{62}$ albo zachowanie tajemnicy jest w interesie ogółu ${ }^{63}$. Jako przykład takiej sytuacji (gdyż przepis o obowiązku składania zeznań w przypadku zwolnienia dotyczy szerszej

57 Tamże, 2312, nb. 43.

58 Jurzyk 2004, 76-77.

59 Eichele 2007, 905, nb. 8. Por. Berger 1999, 306, nb. 27; Baumbach, Lauterbach, Albers i Hartmann 1999, 1489, nb. 1-2.

60 Damrau 2008, 2316, nb. 1; Trautwein 2010, 1060, nb. 7.

61 Reichold 2012, 652, nb. 8. Por. Damrau 2008, 2306, nb. 22; Huber 2009, 1256, nb. 6; Berger 1999, 285, nb. 37.

62 Damrau 2008, 2318, nb. 6.

63 Greger 2016, 1241, nb. 7. Por. Berger 1999, 303-04, nb. 11-12. 
kategorii świadków) wskazuje się przypadek duchownych zarówno uznanych, jak i nieuznanych wyznań, gdyż ich tajemnica stanowi gwarancję instytucjonalną, przekraczając swoim zakresem ochronę interesów poszczególnych osób, co powoduje, że zwolnienie z obowiązku zachowania tajemnicy w ich przypadku jest irrelewantne ${ }^{64}$.

Zwolnienie pozostaje również bez znaczenia w tych przypadkach, w których przepisy szczególne przewidują bezwzględnie możliwość uchylenia się od obowiązku złożenia zeznań przez duchownego. Do przepisów tych zaliczyć należy przede wszystkim w odniesieniu do duchownych katolickich art. 9 konkordatu Rzeszy Niemieckiej z 1933 r. ${ }^{65}$ oraz art. 144 ust. 3 Konstytucji Bawarii ${ }^{66}$, na mocy którego duchowni wspólnot religijnych są uprawnieni do odmowy zeznań także pomimo zwolnienia z obowiązku zachowania tajemnicy ${ }^{67}$.

\section{INNE SYTUACJE TAJEMNICY DUCHOWNEJ}

Tak polskie, jak i niemieckie, unormowania postępowania cywilnego w zakresie prawa odmowy zeznań przez duchownego zawierają ograniczenie przedmiotowe - odpowiednio: do faktów powierzonych na spowiedzi oraz faktów powierzonych w ramach sprawowania duszpasterstwa. Zarazem aktywność duchownych, z którą można wiązać poufność, nie ogranicza się wyłącznie do tych dwóch obszarów. Można tutaj wskazać przykładowo wiedzę uzyskaną przez duchownych w związku z pełnieniem przez nich funkcji (sędziego, adwokata kościelnego, obrońcy węzła małżeńskiego) w ramach postępowań przed trybunałami kościelnymi. Nawet na gruncie przedmiotowo szerszej regulacji kodeksu niemieckiego, mogą być wątpliwości co do kwalifikacji tych funkcji jako związanych ze sprawowaniem duszpasterstwa.

64 Zob. Greger 2016, 1241, nb. 7. Por. Berger 1999, 304, nb. 16-17.

65 Konkordat z dnia 20 lipca 1933 r. pomiędzy Stolicą Apostolską a Rzeszą Niemiecką, RGB1. z 1933 r., Nr 38, 679-90.

66 Konstytucja Wolnego Państwa Bawaria z dnia 2 grudnia 1946 r., tekst jedn. GVB1. z 1998 r., Nr 26, 991-1010.

${ }_{67}$ Zob. Huber 2009, 1260, nb. 6; Trautwein 2010, 1061, nb. 7, Berger 1999, 304, nb. 16 oraz Baumbach Lauterbach, Albers i Hartmann 1999, 1483, nb. 5 i 1490, nb. 8. 
W ramach polskiego Kodeksu Postępowania Cywilnego ewentualnej ochrony duchowni mogliby teoretycznie poszukiwać w art. $261 \S 2$ zd. 1, w szczególności podnosząc, że naruszenie poufności oczekiwanej od duchownego mogłoby narazić go na hańbę, choć nie jest pewne czy taką interpretację podzieliłyby polskie sądy, tym bardziej że wykładnia taka jest dyskusyjna. Powołana regulacja ma bowiem chronić przede wszystkim przed obowiązkiem ujawnienia faktów, które narażają na hańbę a nie przed hańbiącym faktem samego zeznawania (niemniej jednak redakcja przepisu nie wyklucza a limine przedstawionej interpretacji). Trudniej przyjąć, że duchowny mógłby powołać się na tajemnicę zawodową, o której mowa w powołanym przepisie. Po pierwsze, tajemnica zawodowa duchownych nie została wprowadzona explicite żadnym przepisem ustawy. Ewentualnych jej podstaw można by upatrywać w zasadzie wyrażonej w art. 12 ust. 1 zd. 2 ustawy o gwarancjach wolności sumienia i wyznania, który przewiduje zwolnienie duchownych z obowiązków niemożliwych do pogodzenia z pełnieniem funkcji duchownego. W świetle jednak tego samego przepisu zwolnienie to ma zastosowanie ,w ramach obowiązujących przepisów ustaw”, co przemawia przeciwko takiej wykładni. Ponadto, gdyby przyjąć, że duchownych dotyczy tajemnica zawodowa, o której mowa w art. 261 $\S 2$ zd. 1 in fine k.p.c., to wobec niewątpliwego obejmowania wówczas przez nią spowiedzi, art. $261 \S 2$ zd. 2 k.p.c. stanowiłby superfluum, co stoi w sprzeczności z zasadą takiego interpretowania tekstów prawnych, by każda jego jednostka miała sens normatywny. Najprawdopodobniej właśnie z tych powodów, uwzględniając także wykładnię systematyczną, odróżnia się tajemnicę zawodową od tajemnicy spowiedzi ${ }^{68}$. W rezultacie niektóre z aktywności osób duchownych, z którymi wiąże się uzyskiwanie informacji, co do których oczekuje się zachowania ich w poufności, mogą nie być dostatecznie chronione.

Szczególnie więc interesująca jest odpowiednia, zapełniająca analogiczną lukę (w zakresie czynności nie związanych z duszpasterstwem) regulacja niemiecka. W $\S 383$ ust. 1 pkt 6 ZPO przewidziano możliwość odmowy zeznań przez osoby, które sprawują urząd, stanowisko lub wykonują zawód, który ze względu na swą naturę lub przepis ustawy związane

68 Zob. Flaga-Gieruszyńska 2017, 521, teza 5 i 6; Knoppek 2013, 919, teza 16. Por. jednak Rakoczy 2003, 132. 
są z obowiązkiem zachowania tajemnicy wobec powierzonych im faktów odnośnie okoliczności, na które rozciąga się obowiązek zachowania tajemnicy. W konsekwencji, także w przypadku duchownych, nie jest wymagane istnienie przepisu ustawy przewidującego obowiązek zachowania tajemnicy, co daje sądowi możliwość dostosowania do zmieniających się realiów. Powierzenie na gruncie $\S 383$ ust. 1 pkt 6 ZPO oznacza każde uzyskanie informacji $\mathrm{w}$ ramach stosunku zaufania (Vertrauenstellung) i obejmuje ono również wiedzę uzyskaną przypadkowo w ramach takiego stosunku ${ }^{69}$. Wskazuje się przy tym, że sąd badając wymienione przesłanki prawa odmowy zeznań powinien uwzględniać zwłaszcza oczekiwania osób przekazujących informacje $\mathrm{e}^{70}$.

PODSUMOWANIE

Przepisy polskiej procedury cywilnej w zakresie prawa odmowy zeznań różnią się znacząco od analogicznych unormowań niemieckiego kodeksu postępowania cywilnego. Po pierwsze, w przeciwieństwie do rozwiązań niemieckich, w Polsce trudno dokonać jednoznacznej klasyfikacji uprawnień duchownego w zakresie odmowy zeznań, a przepisy ich dotyczące zdają się niejako zamieszczone w przypadkowym miejscu. Odnośnie podmiotowego zakresu powołanego prawa regulacje te są podobne, choć w przypadku polskiego kodeksu ograniczenie katalogu uprawnionych do duchownych tzw. wyznań uznanych budzi daleko idące wątpliwości, a nawet w Republice Federalnej Niemiec, pomimo konstytucyjnych podstaw wyróżniania wspólnot religijnych o statusie publicznoprawnym, pojawiają się głosy o konieczności odrzucenia takiego ograniczenia wobec zasady równouprawnienia kościołów i innych związków wyznaniowych. Również judykatury obu państw zdają się podążać w podobnym kierunku, interpretując pojęcie „duchownego".

Odmiennością o zasadniczym charakterze jest ograniczenie w Polsce prawa odmowy zeznań tylko co do faktów powierzonych na spowiedzi, podczas gdy prawodawca niemiecki chroni fakty powierzone w ramach

69 Reichold 2012, 651-52, nb. 4 i 6.

70 Tamże, 652, nb. 7. Por. Huber 2009, 1256, nb. 4; Eichele 2007, 902, nb. 9. 
sprawowania szeroko rozumianego duszpasterstwa. W efekcie zakres zastosowania przepisów polskiego Kodeksu Postępowania Cywilnego jest stosunkowo wąski ${ }^{71}$. Niezależnie od powyższego penitent w Polsce nie ma możliwości wpływu na skorzystanie przez duchownego z prawa odmowy zeznań, nawet jeśli zeznania te byłyby w jego interesie. W szczególności nie może zwolnić duchownego od obowiązku zachowania tajemnicy. Regulacje Kodeksu Postępowania Cywilnego narażają penitenta na niebezpieczeństwo także wtedy, gdy pomimo obowiązku poufności duchowny zechce złożyć zeznania ${ }^{72}$. Pewnych rozwiązań w tym zakresie dostarczają odmienne uregulowania niemieckie, które przewidują możliwość skutecznego zwolnienia duchownego z obowiązku zachowania tajemnicy (o ile duchowny $z$ innej racji niż tylko wola osoby powierzającej informację nie ma obowiązku dalszego zachowania informacji w poufności), starając się godzić interesy duchownego i osoby powierzającej mu informacje. Tym samym przepisy niemieckie dają przykład rozwiązania kompromisowego, które unika niedoskonałości obecnych rozwiązań polskich, a zarazem rozwiązuje problem występujący na gruncie zgłaszanego niekiedy postulatu wprowadzenia w polskim kodeksie bezwzględnego zakazu dowodowego ${ }^{73}$, który jest zbyt daleko idący i który uniemożliwiłby złożenie zeznań przez duchownego nawet w sytuacji, gdy tylko on jest zainteresowany w utrzymaniu informacji w tajemnicy (chodzi tu o takie sytuacje, gdy nawet prawo wewnętrzne wspólnoty religijnej dopuszcza zwolnienie z obowiązku poufności, a więc nie o przypadek duchownych Kościoła Katolickiego).

Godnym odnotowania jest także występujący w Niemczech obowiązek unikania w miarę możliwości przez sąd pytań, które w oczywisty sposób godziłyby w obowiązek zachowania przez duchownego powierzonych mu informacji w tajemnicy. Ważną wskazówką dla polskiego prawodawcy może być również poszerzenie możliwości odmowy zeznań o sytuacje ogólnego stosunku zaufania, który w zakresie duchownych obejmowałby także inne sytuacje niż tylko związane ze spowiedzią czy samym tylko duszpasterstwem. Natomiast polski Kodeks Postępowania Cywilnego

71 Por. Majer 2002, 113-14; Jurzyk 2004, 73-74.

72 Jurzyk 2004, 79.

73 Zob. m.in. Rakoczy 2003, 138; Szymański 2017, 84; Pieron 2012, 333; Pieron 2016, 133 i 148. Tak również wydaje się: Stanisz 2011, 294. 
może stanowić wzorzec dla prawodawcy niemieckiego w zakresie obowiązku pouczenia duchownego o przysługującym mu prawie odmowy składania zeznań.

BIBLIOGRAFIA

Banaszak, Bogusław i Agnieszka Malicka. 2008. Konstytucja Niemiec, Warszawa: Wydawnictwo Sejmowe.

Baumbach, Adolf, Wolfgang Lauterbach, Jan Albers i Peter Hartmann. 1999. Zivilprozessordnung: mit Gerichtsverfassungsgesetz und anderen Nebengesetzen. München: C.H. Beck.

Berger, Christian. 1999. W: Kommentar zur Zivilprozeßordnung, t. 4, cz. 2: $\S \S 348-510 b$, red. Friedrich Stein, Martin Jonas. Tübingen: J.C.B. Mohr (Paul Siebeck).

Classen, Claus D. 2006. Religionsrecht. Tübingen: Mohr Siebeck.

Cudak, Arkadiusz. 2016. W: Kodeks postepowania cywilnego, t. I: Komentarz. Art. 1-366, red. Andrzej Marciniak, Kazimierz Piasecki. Warszawa: Wydawnictwo C.H. Beck.

Damrau, Jürgen. 2008. W: Münchener Kommentar zur Zivilprozessordnung mit Gerichtsverfassungsgesetz und Nebengesetzen, t. 1: $\$$ 1-510c, red. Thomas Rauscher, Peter Wax, Joachim Wenzel. München: Verlag C.H. Beck.

Demendecki, Tomasz. W: Kodeks postępowania cywilnego, t. I: Komentarz do art. 1-729, red. Andrzej Jakubecki. Warszawa: Wolters Kluwer.

Domaszk, Arkadiusz. 2016. „Kierownictwo duchowe alumnów seminariów duchownych i zakonników w prawie kanonicznym (II): zachowanie tajemnicy”. Seminare 3: 35-45.

Dubisz, Stanisław, red. 2003. Uniwersalny słownik języka polskiego, t. 3: P-Ś. Warszawa: Wydawnictwo Naukowe PWN.

Eichele, Hans. 2007. W: Zivilprozessordnung: Handkommentar, red. Ingo Saenger. Baden-Baden: Nomos Verlagsgesellschaf.

Ereciński, Tadeusz. 2016. W: Kodeks postępowania cywilnego. Komentarz, t. II: Postępowanie rozpoznawcze, red. Tadeusz Ereciński. Warszawa: Wolters Kluwer.

Flaga-Gieruszyńska, Kinga. 2017. W: Kodeks postępowania cywilnego. Komentarz, red. Andrzej Zieliński. Warszawa: Wydawnictwo C.H. Beck.

Friedner, Lars. 2007. „Religious Entities as Legal Persons - Germany”. W: Churches and Other Religious Organisations as Legal Persons: proceedings 
of the 17th meeting of the European Consortium for Church and State Research, Höör (Sweden), 17-20 November 2005, red. Lars Friedner. Leuven, Paris, Dudley (MA): Peeters.

Fundowicz, Sławomir. 1999. „Osobowość publicznoprawna wspólnot religijnych w Niemczech". W: Studia z prawa publicznego, t. I: Współczesne problemy prawa publicznego, red. Sławomir Fundowicz. Lublin: Towarzystwo Naukowe Katolickiego Uniwersytetu Lubelskiego.

Greger, Reinhard. 2016. W: Zivilprozessordnung: mit FamFG (\$\$ 1-185, 200-270, 433-484) und Gerichtsverfassungsgesetz, den Einführungsgesetzen, mit Internationalem Zivilprozessrecht, EG-Verordnungen, Kostenanmerkungen: Kommentar, red. Richard Zöller. Köln: Verlag Dr. Otto Schmidt.

Huber, Michael. 2009. W: Kommentar zur Zivilprozessordnung: mit Gerichtsverfassungsgesetz, red. Hans-Joachim Musielak. München: Verlag Franz Vahlen. Janicki, Lech, red. 2007. Ustawa zasadnicza Republiki Federalnej Niemiec, Poznań: Instytut Zachodni.

Jurzyk, Marek. 2004. „Ochrona spowiedzi w postępowaniu dowodowym a prawa penitenta i duchownego". Radca Prawny 2: 67-81.

Knoppek, Krzysztof. 2013. W: Kodeks Postępowania Cywilnego, t. I: Artykuły 1-366, red. Henryk Dolecki, Tadeusz Wiśniewski. Warszawa: Wolters Kluwer.

Majer, Piotr. 2002. „Ochrona prywatności w kanonicznym porządku prawnym”. W: Ochrona danych osobowych i prawo do prywatności w Kościele, red. Piotr Majer, 83-123. Kraków: Wydawnictwo Naukowe Papieskiej Akademii Teologicznej

Pieron, Bartłomiej. 2012. „Ochrona tajemnicy spowiedzi w prawie polskim”. Kieleckie Studia Teologiczne 11: 321-334.

Pieron, Bartłomiej. 2016. „Tajemnica zawodowa (duszpasterska) duchownego”. Annales Canonici 12: 131-153, http://dx.doi.org/10.15633/acan.1824.

Pieron, Bartłomiej. 2017. „Równe czy identyczne traktowanie osób duchownych w prawie polskim?". Annales Canonici 13: 155-181, http://dx.doi. org/10.15633/acan.2224.

Pieróg, Michał. 2015. „Tajemnica spowiedzi świętej w prawie kanonicznym, polskim procesie cywilnym i karnym". Studia Paradyskie 25: 169-180.

Rakoczy, Bartosz. 2003. „Tajemnica spowiedzi w polskim postępowaniu cywilnym, karnym i administracyjnym". Przeglad Sądowy 11-12: 126-138.

Reichold, Klaus. 2012. W: Zivilprozessordnung: FamFG Verfahren in Familiensachen, GVG, Einführungsgesetze, EU-Zivilverfahrensrecht: Kommentar, red. Heinz Thomas, Hans Putzo. München: C.H. Beck.

Robbers, Gerhard. 2010. Religion and Law in Germany. Alphen aan den Rijn: Kluwer Law International. 
Skąpski, Andrzej. 1981. Ograniczenia dowodzenia w procesie cywilnym. Warszawa, Kraków: Państwowe Wydawnictwo Naukowe.

Stanisz, Piotr. 2011. „Sytuacja prawna osób duchownych”. W: Artur Mezglewski, Henryk. Misztal, Piotr Stanisz, Prawo wyznaniowe, 289-313. Warszawa: Wydawnictwo C.H. Beck.

Strzała, Marek. 2017. „Szczególny status duchownych wobec powszechnego obowiązku obrony w Republice Austrii i Republice Federalnej Niemiec". W: Wolność sumienia i religii a bezpieczeństwo i porzadek publiczny, red. Jerzy Nikołajew, Paweł Sobczyk, Konrad Walczuk, 107-118. Warszawa: Wydawnictwo Diecezji Siedleckiej UNITAS.

Szymański, Michał. 2017. „Tajemnica spowiedzi w prawie polskim - stan aktualny i propozycje zmian". Internetowy Przeglad Prawniczy TBSP UJ 4: 73-85. Śladkowski, Mariusz. 2015. „Fakty powierzone duchownemu podczas spowiedzi jako przedmiot zeznań w postępowaniu cywilnym, karnym i administracyjnym". W: Wolność wypowiedzi versus wolność religijna. Studium z zakresu prawa konstytucyjnego, karnego i cywilnego, red. Artur Biłgorajski, 271-282. Warszawa: Wydawnictwo C.H. Beck.

Trautwein, Thomas. 2010. W: ZPO: Kommentar, red. Hanns Prütting, Markus Gehrlein. Köln: Luchterhand.

\section{THE RIGHT TO REFUSE TESTIMONY BY A CLERGYMAN IN THE POLISH AND GERMAN CIVIL PROCEDURE - A LEGAL COMPARATIVE STUDY}

\section{Summary}

Section 261 para. 2 of the Polish Code of Civil Procedure provides for the possibility to refuse testimony by a clergyman regarding facts revealed to him during confession. This regulation differs from other Polish legal procedures, which usually treat such facts as inadmissible evidence. There is an ongoing debate in the doctrine about changing the rules of the civil procedure, which, as many authors argue, does not properly protect the clergy and people who reveal information to them. Given that, a point of reference can be sought in foreign regulations, which may provide ready solutions or indicate the right direction of normative changes as well as shed some light on some potential problems with the interpretation and application of regulations already introduced in other countries. This article aims to present the regulations of the German Zivilprozessordnung concerning the clergyman's right to refuse testimony and to compare them with the current provisions 
of the Polish Code of Civil Procedure. The legal-comparative analysis concerns the model of legal regulation of the right to refuse testimony by clergymen, the subjective and objective scope of this right, the duty of the judge to advise the clergyman of his rights, the admissibility of the clergyman's testimony and the issue of protecting information revealed to clergymen outside his pastoral service.

Key words: clergyman; witness; testimony; confession; right to refuse to testify; code of civil procedure; civil proceedings - Poland - Germany; Polen - Deutschland - der Geistliche; das Zivilprozessordnung; das Zeugnisverweigerung

Ttumaczenie własne autora 